\title{
A comparative morphological study of the epiandrous apparatus in mygalomorph spiders (Araneae, Mygalomorphae)
}

\author{
N. Ferretti ${ }^{a, *}$, G. Pompozzi $^{\text {b }}$, S. Copperi ${ }^{\text {b }}$, A. Wehitt ${ }^{c}$, E. Galíndez $^{c}$, A. González $^{\text {a }}$, \\ F. Pérez-Miles ${ }^{d}$ \\ a Centro de Estudios Parasitológicos y de Vectores (CEPAVE), UNLP, CONICET, Boulevard 120s/n e/61 y 62, La Plata 1902, Argentina \\ ${ }^{\mathrm{b}}$ Instituto de Ciencias Biológicas y Biomédicas del Sur (INBIOSUR), UNS, CONICET, San Juan 670, Bahía Blanca 8000, Argentina

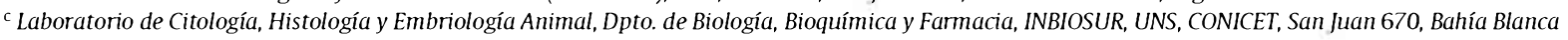 \\ 8000, Argentina \\ ¿ Facultad de Ciencias, Sección Entomología, Igua 4225, Montevideo 11400, Uruguay
}

\section{A R T I C L E I N F O}

\section{Article history:}

Received 30 September 2016

Received in revised form 5 November 2016

Accepted 5 November 2016

Available online 15 November 2016

\section{Keywords:}

Spiders

Mygalomorphae

Ultrastructure

Histology

Epiandrous spigots

Epiandrous glands

\begin{abstract}
A B S T R A C T
Many adult male spiders have silk glands which are not associated with the spinnerets. They occur on the anterior margin of the genital furrow and are used during the building of the sperm web and sperm droplet induction. These epiandrous glands exit the body through ducts which lead to specialized spigots. In the taxon Mygalomorphae, the presence of epiandrous spigots is just reported for a couple of species but their morphology has not been investigated. In this paper we provide a detailed study of the ultrastructure morphology of eighteen species belonging to eight families using light and scanning electron microscopy (SEM). We describe and present images of the epiandrous spigots above the genital opening. Also, we compare the morphology of spigots between families and describe the epiandrous glands through histology.
\end{abstract}

(c) 2016 Elsevier Ltd. All rights reserved.

\section{Introduction}

When a male spider reaches its sexual maturity, he charges his palpal organs with sperm (Foelix, 2011). First, he spins a sperm web that is suspended horizontally and then the male crawls under the web, turns upside down, and presses his abdomen against the rim of the web while making intensive movements with his abdomen (from side to side on tarantulas) until a drop of seminal fluid emerges from his genital opening (Foelix, 2011; Rojas-Buffet \& Viera, 2016). A small area of this mat is reinforced and the sperm droplet is deposited there. Thereafter, the male (of many species) moves to the underside of the sperm web and touches with his palps around the margin of the web and the palpal organs are dipped alternately into the sperm drop (Foelix, 2011).

\footnotetext{
* Corresponding author at: Centro de Estudios Parasitológicos y de Vectores (CEPAVE), UNLP, CONICET, Boulevard 120s/n e/61 y 62, La Plata 1902, Argentina.

E-mail addresses: nferretti@conicet.gov.ar (N. Ferretti), gabrielpompozzi@conicet.gov.ar(G.Pompozzi),sofia.copperi@uns.edu.ar (S.Copperi), anahiwehitt@gmail.com (A.Wehitt),galindez@criba.edu.ar (E.Galíndez),asgonzalez@cepave.edu.ar(A.González),myga@fcien.edu.uy (F. Pérez-Miles)
}

Many adult male spiders have additional silk glands which are not associated with the spinnerets but occur on the anterior margin of the genital furrow (Marples, 1967). They were named "epiandrous glands" by Marples, but authors of later studies preferred to refer to them as epigastric glands (Legendre and Lopez, 1971, 1981; Legendre, 1972; Kotzman, 1988). Like "true" silk glands, they exit the body through cuticular ducts which usually lead to specialized hollow setae or spigots. In this way, the glands and the spigots located in front of the genital opening are known as "epigastric apparatus" (Lopez and Emmerit, 1988) or "epiandrous apparatus" (Michalik and Uhl, 2005), the latest expression will be used along the present work. The epiandrous spigots are located immediately anterior to the genital furrow (Kotzman, 1988; Kuntner, 2005; Labarque et al., 2009; Ramírez, 2014) and are present, albeit sporadically, in most spider lineages (Marples, 1967; Lopez and Emerit, 1988) including liphistiids (Legendre and Lopez, 1981) making them a potential synapomorphy of spiders. The function of the produced silk is poorly understood, but it is used during the building of the sperm web and sperm droplet induction (Knoflach, 1998, 2004). In most araneomorph spiders the sperm web is rather small, but theraphosids (tarantulas) construct relatively large sperm mats (Costa and Pérez-Miles, 2002). According to Melchers (1964), the eppiandrous secretion appears to form that portion of the sperm web on which the seminal fluid is 
deposited, and maybe analogous to spermatophores known from primitive arachnids (Shultz, 1987). The epiandrous silk may "reinforce" the sperm web (Knoflach, 1998), or may possible play a role in maintaining the sperm droplet as it is being taken up by the male palpal organs because epiandrous silk is mostly limited to the zone where the sperm drop is deposited (Costa and PérezMiles, 2002). For some spider families, unicellular glands that open next to the genital opening via individual ducts are described, but it is unknown whether the glandular secretion is added to the seminal fluid originating from the primary male reproductive system (López, 1974, 1987). Although epiandrous glands are usually present in all male spiders their extent may vary considerably. Further, many male spiders, especially those of small sized taxa such as erigonine linyphiids (Miller, 2007) and small theridiids (Agnarsson, 2004), lack epiandrous spigots (see also Marples, 1967). Hence, the function of epiandrous silk seems readily replaced by other spigots types, but we are unaware of studies showing sperm web construction in males that lack epiandrous spigots.

In mygalomorph spiders, the presence of epiandrous spigots is sporadically reported for some species of Apomastus (Cyrtaucnheniidae) (Bond, 2004), Aliatypus (Antrodiaetidae) (Coyle, 1975) and in Grammostola mollicoma (Theraphosidae) (Melchers, 1964), but their report is missing in most of modern systematic works. Kotzman (1988) mentioned the presence of "fusules" in juvenile Selenocosmia stirlingi Hogg, 1901. Marples (1967) examined one theraphosid species and according to the conclusion of the author the presence of fusules seemed to be doubtful.

Because currently there are no explicit descriptions of the fine structure of epiandrous spigots in Mygalomorphae, herein, we analyze the presence of epiandrous spigots and provide a detailed morphological description and compare the morphometric variation in 18 mygalomorph species representative of the families Actinopodidae, Dipluridae, Idiopidae, Mecicobothriidae, Microstigmatidae, Migidae, Nemesiidae and Theraphosidae by using stereoscopic microscopy and scanning electron microscopy. Also, we present the description of the morphology of epiandrous glands by using sections for light microscope in the species Acanthogonatus centralis (Nemesiidae) and Grammostola vachoni (Theraphosidae).

\section{Material and methods}

\subsection{Samples}

Twenty aldult males of mygalomorph spiders were analyzed. Specimens were preserved in $80 \%$ etanol and deposited in the following collections: Arachnological collection of the Facultad de Ciencias (FCE-MY), Montevideo, Uruguay; Museo de La Plata (MLP), La Plata, Argentina; and Laboratorio de Zoología de Invertebrados II (LZI), Universidad Nacional del Sur, Bahía Blanca, Argentina.

\subsubsection{Material examined}

2.1.1.1. Mecicobothriidae. Mecicobothrium thorelli Holmberg, 1882 , $10^{\circ}$ Argentina, Buenos Aires, Tornquist, Parque Provincial Ernesto Tornquist, 15 Sep 2010, Ferretti col. (LZI236)

2.1.1.2. Dipluridae. Diplura paraguayensis (Schiapelli and Gerschman, 1940), 10 Argentina, Misiones, Belgrano, Reserva de Vida Silvestre Urugua-í, 4 Oct 2014, Pompozzi col. (LZI333). Ischnothele annulata Tullgren, 1905, 1 Argentina, Córdoba, Calamuchita, Los Molinos, 10 Feb 2014, Pompozzi col. (LZI434).

2.1.1.3. Actinopodidae. Actinopus sp., 1 Argentina, Buenos Aires, Tornquist, Parque Provincial Ernesto Tornquist, Feb 2010, Ferretti col. (LZI136)
2.1.1.4. Theraphosidae. Ischnocolinae: Catumiri parvum (Keyserling, 1878), 10 Argentina, Buenos Aires, Isla Martín García, 20 Sept 2011, Pompozzi col. (LZI286). Theraphosinae: Euathlus sp., 10 Argentina, Neuquén, Huilches, 20 Oct 2011, Ferretti col. (LZI279). Grammostola doeringi (Holmberg, 1881), 10 Argentina, Río Negro, Choele Choel, 24 Oct 2010, Ferretti col. (LZI288). Grammostola vachoni Schiapelli and Gerschman, 1961, 2 Argentina, Buenos Aires, Tornquist, Sierra de la Ventana, 25 Jan 2011, Ferretti col. Hapalotremus martinorum Cavallo and Ferretti, 2015, 10 Argentina, Salta, near route 33, Cavallo, Gamache and Hüsser cols. (MLP19152). Homoeomma uruguayense (Mello-Leitão, 1946), $1 \sigma^{\prime}$ Uruguay, Montevideo (FCE-MY).Melloleitaoina uru Perafán and Pérez-Miles, 2014, $1{ }^{\prime}$ Argentina, Salta, Barneche col. (LZI435). Plesiopelma longisternale (Schiapelli and Gerschman, 1942), $1{ }^{\dagger}$ Argentina, Buenos Aires, Tornquist, Sierra de la Ventana, 6 Oct 2009, Copperi col. (LZI75).

2.1.1.5. Microstigmatidae. Xenonemesia platensis Goloboff, 1989, 10 Argentina, Buenos Aires, Isla Martín García, 23 Sep 2011, Ferretti col. (LZI436)

2.1.1.6. Nemesiidae. Acanthogonatus centralis Goloboff, 1995, 2 Argentina, Buenos Aires, Tornquist, Parque Provincial Ernesto Tornquist, 30 Sept 2009, Ferretti col. (LZI167). Diplothelopsis ornata Tullgren, 1905, $1 \sigma^{\text {t }}$ Argentina, Mendoza, Santa Rosa, Reserva Ñacuñán, 12 Feb 2013, Ferretti col. Stenoterommata platensis Holmberg, 1881, 1 ` Argentina, Buenos Aires, Isla Martín García, 5 May 2005, Barneche col. (LZI437).

2.1.1.7. Migidae. Calathotarsus simoni Schiapelli and Gerschman, 1975, 1 Argentina, Buenos Aires, Tornquist, Estancia Funke, Oct 2013, Ferretti col. (LZI384)

2.1.1.8. Idiopidae. Idiops sp., 10 Argentina, Córdoba, Pocho, Parque Natural Provincial y Reserva Forestal Natural Chancani, 12 Jan 2010, Nime col. (LZI438)

\subsection{Preparation for scanning electron microscopy (SEM) and histology}

An area comprising the proximal part of the abdomen next to the genital opening was detached from the specimens and cleaned with $80 \%$ ethanol. Each sample was proceeded to critical point drying (POLARON E3000), using Carbon Dioxide $\left(\mathrm{CO}_{2}\right)$ as transitional fluid. Sample structure was mounted by placing it on a piece of double sided sticky carbon tape on an aluminum stub. The last step of preparation before taking the SEM images involved sputtering coating by using gold in Argon with plasma current (SPI Module ${ }^{\mathrm{TM}}$ ). The examinations were made under variable pressure conditions using a JEOL JSM-35CF (JEOL Ltd., Japan) and a JSM-5900LV (JEOL, USA Inc., USA) scanning electron microscopes. The microscopes were operated at high vacuum.

For histological approach, the abdomen of one adult male of Grammostola vachoni (Theraphosidae) and an adult male of Acanthogonatus centralis (Nemesiidae) were fixed in Dubosq-Brasil solution and embedded in Paraplast ${ }^{\circledR}$. Tissue sections of $5 \mu \mathrm{m}$ thickness were cut using a Leica RM 2145 rotary microtome, and stained with hematoxylin-eosin and Masson's trichromic protocols for morphologic analysis. The periodic acid Schiff (PAS) reaction and the Alcian blue $(\mathrm{AB})$ technique at $2.5 \mathrm{pH}$ level were employed to analyze the glycoprotein distribution. The slides were observed with a Nikon AFM microscope and were digitalized with an Olympus Camedia Mod.C-7070 Wide Zoom. 


\subsection{Measurements and illustrations}

Measurements were obtained using TpsDig2 (Rohlf, 2006) and given in micrometers. Morphometric statistics were calculated using SPSS version 14.0 (2005) and the freely available statistical package PAST 3.0 (Hammer et al., 2008); error factors are given as standard deviations (SD). Normality and homogeneity of data and variances were evaluated with Levene and Shapiro-Wilk tests. Analysis of variance (ANOVA) and non-parametric Kruskal-Wallis tests were used for comparisons of morphometric parameters of multiple groups, and the Student $t$-test for paired samples. Spearman correlation coefficient was used to evaluate possible relationships among the size of the spider (measured as the total length not including chelicerae and spinnerets) and of the spigots. Photographs of preserved material were taken using a Sony CyberShot DSC-H2 mounted on a SZ Olympus stereoscopic microscope. All illustrations were edited in Corel Photo Paint $X 7^{\circ}$.

\section{Results}

\subsection{Gross morphology of epiandrous spigots}

In all studied species, the presence of epiandrous spigots is confirmed and they are placed anterior to the genital furrow. The interspecific number of the spigots is highly variable, ranging for example 12 epiandrous spigots present in Mecicobothriidae to more than 100 epiandrous spigots in some Theraphosidae (Table 1). Spigots are arranged in an evident half-moon shape or semicircular area characterized by the following features: i) epiandrous spigots intermixed with different types of plumose setae (mainly in Theraphosidae) (Fig. 1A), and ii) epiandrous spigots intermixed with a few long setae (Actinopodidae, Dipluridae, Idiopidae, Mecicobothriidae, Microstigmatidae, Migidae and Nemesiidae) (Fig. 1B).

Spigots are located approximately perpendicular with respect to the body surface. The general shape of epiandrous spigots consists of an elongated stout setae with a widened base (Fig. 2) with mean lengths of about $87.61 \mu \mathrm{m} \pm 39.33(\mathrm{n}=36)$ and a wide basal portion (Fig. 2) of about $14.89 \mu \mathrm{m} \pm 2.71(n=42)$ mean wide, a narrower distal part (Fig. 2) of about $4.84 \mu \mathrm{m} \pm 0.89(\mathrm{n}=52)$ mean wide and tapering. Epiandrous spigots are inserted in sockets (Fig. 2), mostly of circular shape, others hexagonal, with mean diameters of about $29.22 \mu m \pm 7.04(n=38)$.

\subsection{Comparative morphology of epiandrous spigots}

\subsubsection{Mecicobothriidae (Mecicobothrium thorelli)}

A total of 12 epiandrous spigots were found very close to the genital opening (Table 1) (Fig. 3A). Spigots are inserted in circular rebordered sockets (Fig. 3B) of $13.52 \mu \mathrm{m} \pm 1.5(\mathrm{n}=12)$ in diameter. The spigots are elongated (mean length of $57.5 \mu \mathrm{m} \pm 13.41, \mathrm{n}=12$ ) and a little wider in the basal portion. The basal portion showed a mean width of $5.94 \mu \mathrm{m} \pm 0.94(\mathrm{n}=12)$ and the apical area had a width of $1.96 \mu \mathrm{m} \pm 0.44(\mathrm{n}=12)$. The spigots were completely covered by small ridges along the entire surface in a basal-apical orientation (Fig. 3B). Regarding the intermixed setae with the epiandrous spigots, $M$. thorelli had very long stout setae with small thorns on the surface (Fig. 3B).

\subsubsection{Dipluridae}

Spigots were found very close to the genital opening inserted in circular rebordered sockets and in a number of more than 25 in D. paraguayensis and about 50 in I. annulata (Table 1) (Fig. 3C, E). We found significant differences in the socket diameter $(t=2.33$, $\mathrm{p}=0.03)$, basal width $(t=8.37, \mathrm{p}<0.0001)$, apical width $(t=6.33$, $\mathrm{p}<0.0001)$ and length $(t=15.72, \mathrm{p}<0.0001)$ of epiandrous spigots among $D$. paraguayensis and $I$. annulata. Epiandrous spigots of $D$. paraguayensis are clearly larger than of I. annulata. In D. paraguayensis spigots are more erected (Fig. 3C) than in I. annulata and had very small ridges along the entire surface with small pores (Fig. 3D). Spigots of I. annulata are almost smooth with hardly visible irregular surface (Fig. 3F). Regarding the intermixed setae with the epiandrous spigots, $D$. paraguayensis showed long stout setae with parallel ridges along the entire surface, while in $I$. annulata the setae were very long carrying small thorns on the surface (Fig. 3F).

\subsubsection{Actinopodidae (Actinopus sp.)}

We observed 23 epiandrous spigots very close to the genital opening (Table 1$)$. Spigots are inserted in circular sockets of $22.84 \mu \mathrm{m} \pm 0.5(\mathrm{n}=15)$ in diameter. The spigots are elongated and mostly curved at tip (mean length of $60.53 \mu \mathrm{m} \pm 12.6, \mathrm{n}=15$ ) and a little wider in the basal portion (Fig. $3 G$ ). The basal portion showed a mean width of $12.57 \mu \mathrm{m} \pm 1.7(\mathrm{n}=15)$ and the apical area had a width of $4.3 \mu \mathrm{m} \pm 0.51(n=15)$. The spigots were found to be smooth and evidence of silk release can be seen in Fig. $3 \mathrm{H}$. The setae present in the area of the epiandrous spigots comprised thin setae slightly longer than the spigots (Fig. 3G).

\subsubsection{Theraphosidae}

In all species, spigots were found above the genital opening arranged in an evident half-moon shaped zone (Fig. 4), called, herein, the epiandric area. Spigots are inserted in circular bordered sockets (Fig. 5F) or hexagonal sockets (G. doeringi and G. vachoni) (Fig. 5A-B, D) in a number of more than 30 in most of the species (Table 1). Results from the ANOVA test found significant differences in the socket diameter $(F=115.74, p<0.001)$ and basal width among species $(F=13.62, p<0.001)$. Hapalotremus martinorum was found to have the smallest sockets and basal width, while G. doeringi had the larger sockets and the wider basal portion of the spigots. Also, we found significant differences in the apical width of spigots among species $(F=18.22, p<0.001)$, thus $C$. parvum and $H$. martinorum had the thinner apical part of the spigots while the wider apical portion was observed in Euathlus sp., G. vachoni and $P$. longisternale. Finally, regarding the total length of spigots, we found significant differences between species $(F=16.64, p<0.001)$, with P. longisternale (Fig. 6A), M. uru (Fig. 6E) and Euathlus sp. (Fig. 7A) (in ascending order) having the longer spigots, while H. martinorum had the shorter ones (Fig. 7E).

Grammostola doeringi, G. vachoni and $H$. uruguayense had spigots with smooth surfaces or with little irregular surfaces (Fig. 5B-C, E-F). Plesiopelma longisternale presented spigots with light ornamented scaly surface (Fig. 6B). Catumiri parvum and M. uru spigots had very low ridges along the entire surface of the spigot (Fig. 6D, E). Euathlus sp. had fusules with large short ridges converging in the middle portion of the spigot along the entire length (Fig. 7D). Finally, H. martinorum showed ridges on the spigot surface but also about eight deep transversal straight openings located from the middle to the top of the spigot (Fig. 7F).

Regarding the intermixed setae with the epiandrous spigots, we found that $C$. parvum, G. doeringi, G. vachoni, H. uruguayense and $P$. longisternale presented large pointed plumose setae and a smaller number of short blunt plumose setae (Figs. 5 B, D, F, 6 A). Hapalotremus martinorum showed thinner and thicker types of plumose setae (Fig. 7E-F). In the cases of Euathlus sp. and M. uru, a third type of setae was present in the epiandrous spigots area: Euathlus sp. had very long stout setae with barbs pointed to the apical portion (Fig. 7B-D) and Melloleitaoina uru showed short stout setae with elongated bumps pointed to the apical portion (Fig. 6F).

\subsubsection{Microstigmatidae (Xenonemesia platensis)}

We found about 15 epiandrous spigots very close to the genital opening (Table 1) (Fig. 8A). Spigots are inserted in circular sockets of $16.65 \mu \mathrm{m} \pm 0.93(n=14)$ in diameter. The spigots are 
Table 1

Approximate number of epiandrous spigots and mean values of morphometrics parameters are shown in all studied species.

\begin{tabular}{|c|c|c|c|c|c|c|}
\hline Family & Species & $\begin{array}{l}\text { Approximate } \\
\text { number of spigots }\end{array}$ & Socket diameter & Basal width & Apical width & Length \\
\hline Mecicobothriidae & M. thorelli & 12 & 13.52 & 5.94 & 1.96 & 57.5 \\
\hline \multirow[t]{2}{*}{ Dipluridae } & D. paraguayensis & 25 & 20.13 & 14.22 & 5.27 & 191.88 \\
\hline & 1. annulata & 50 & 16.22 & 9.66 & 2.81 & 72.78 \\
\hline Actinopodidae & Actinopus sp. & 23 & 22.84 & 12.57 & 4.3 & 60.53 \\
\hline \multirow[t]{8}{*}{ Theraphosidae } & C. parvum & 32 & 22.73 & 11.24 & 2.54 & 99.12 \\
\hline & Euathlus sp. & 58 & 25.77 & 13.76 & 5.36 & 162.71 \\
\hline & G. doeringi & 134 & 40.29 & 17.58 & 4.9 & 67.04 \\
\hline & G. vachoni & 127 & 31.52 & 15.25 & 5.77 & 75.69 \\
\hline & H. martinorum & 47 & 12.98 & 7.66 & 1.62 & 38.87 \\
\hline & H. uruguayense & 27 & 24.67 & 15.1 & 4.96 & 44.56 \\
\hline & M. uru & 38 & 25.67 & 12.05 & 4.10 & 129.7 \\
\hline & P. longisternale & 52 & 30.72 & 14.41 & 5.05 & 99.31 \\
\hline Microstigmatidae & $X$. platensis & 15 & 16.65 & 9.85 & 2.48 & 60.53 \\
\hline \multirow[t]{3}{*}{ Nemesiidae } & S. platensis & 28 & 15.54 & 9.84 & 2.39 & 116.2 \\
\hline & A. centralis & 31 & 22.53 & 12.38 & 3.55 & 73.71 \\
\hline & D. omata & 46 & 31.42 & 18.88 & 4.81 & 160.15 \\
\hline Migidae & C. simoni & 27 & 27.55 & 19.33 & 4.79 & 126.96 \\
\hline Idiopidae & Idiops sp. & 18 & 23.32 & 10.96 & 5.39 & 86.81 \\
\hline
\end{tabular}
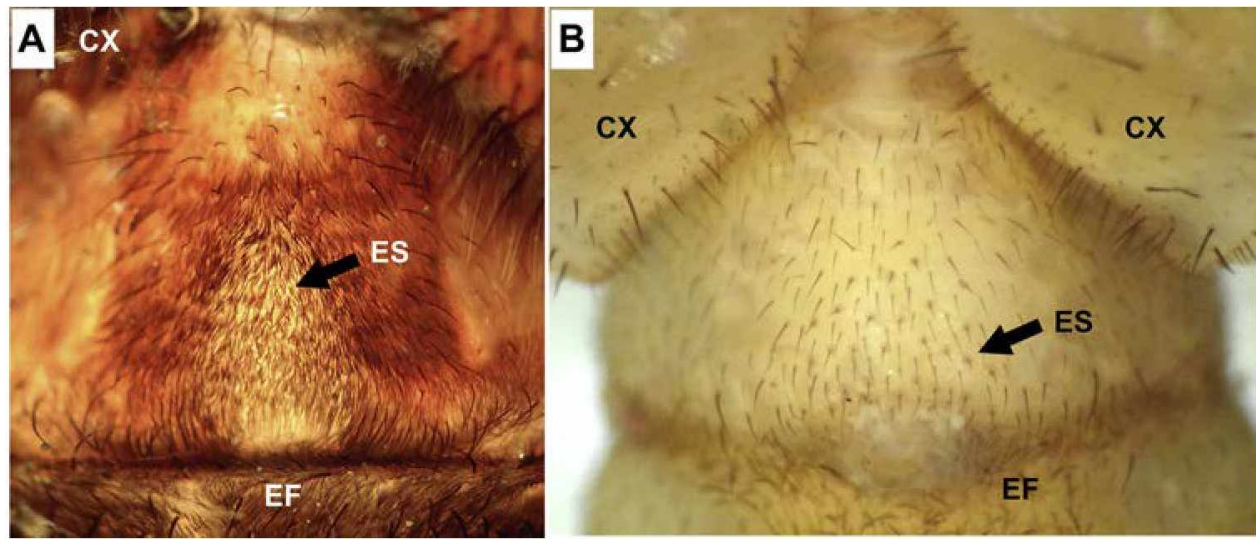

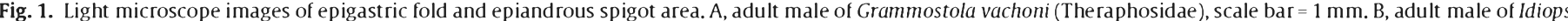
sp., scale bar $=0.5 \mathrm{~mm} . \mathrm{CX}=$ Coxae, $\mathrm{ES}=$ epiandrous spigot, $\mathrm{EF}=$ Epigast ric fold.

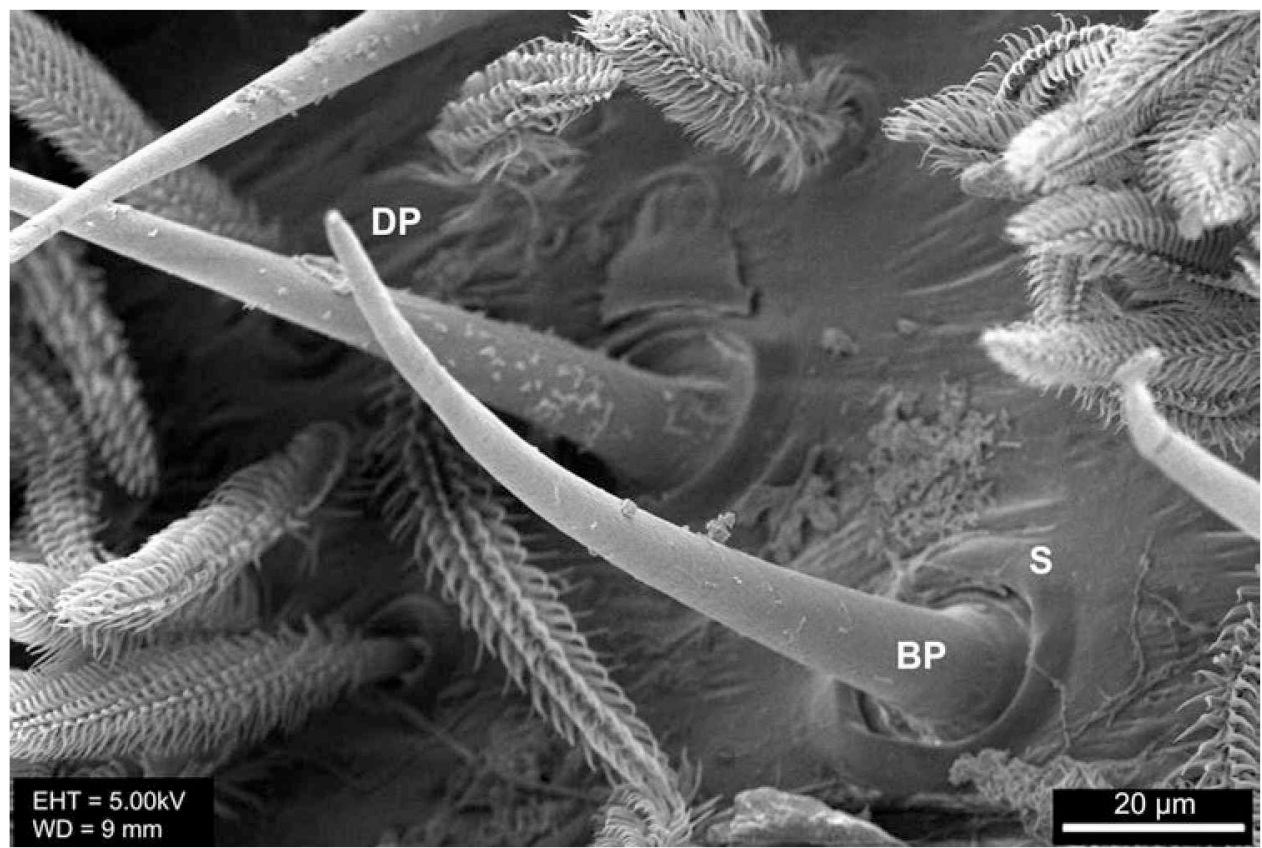

Fig. 2. Scanning electron micrograph showing typical epiandrous spigot morphology. $\mathrm{BP}=$ basal portion, $\mathrm{DP}=$ distal portion, $\mathrm{S}=$ socket 

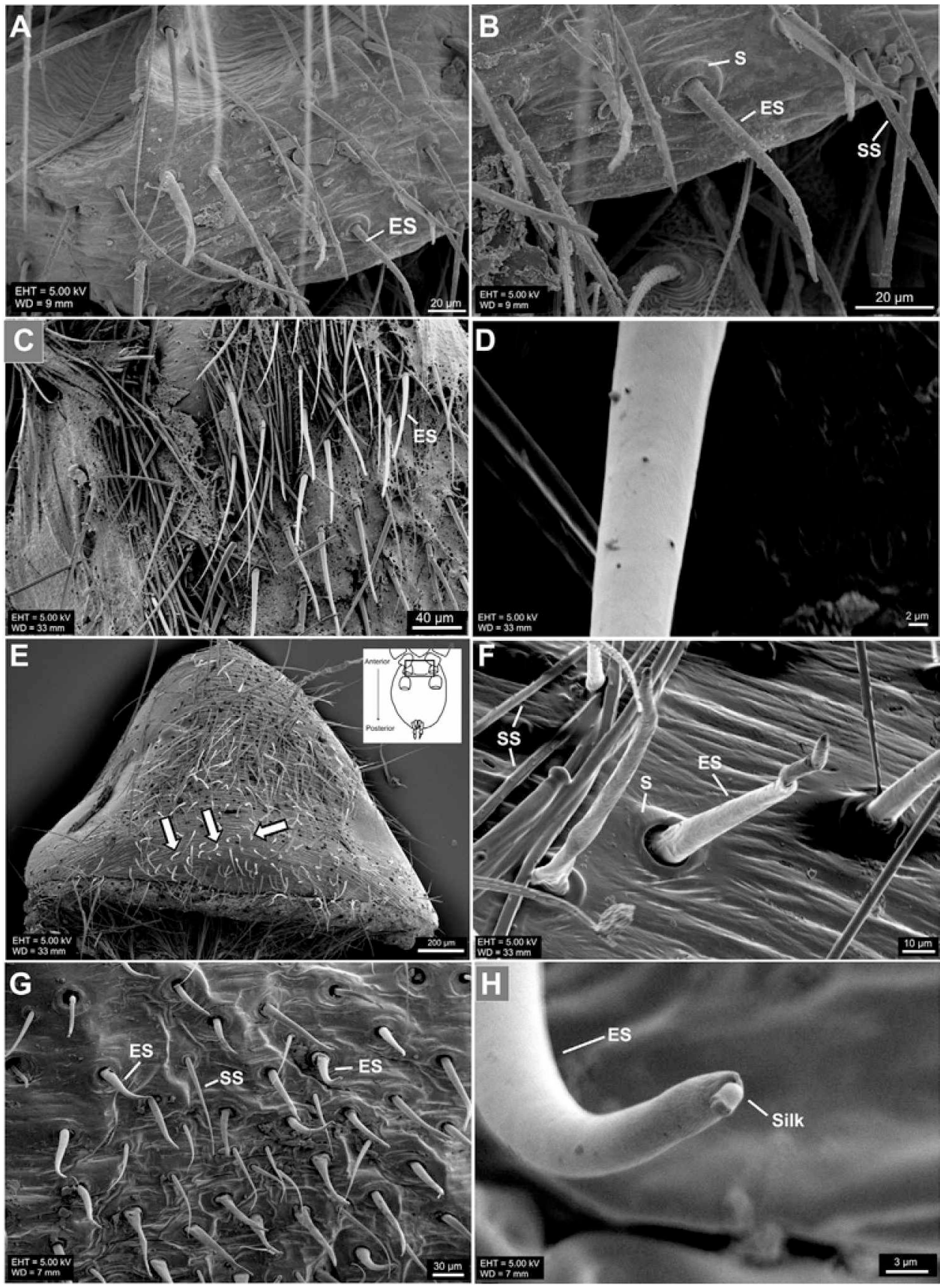

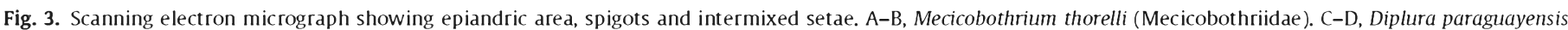

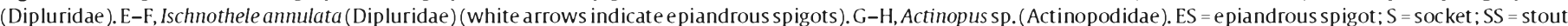
setae.

widened at base and elongated becoming thinner (mean length of $60.53 \mu \mathrm{m} \pm 12.6, \mathrm{n}=14$ ) and much wider basally than apically (Fig. 8C). The basal portion showed a mean width of $9.85 \mu \mathrm{m} \pm 1.05$ $(n=15)$ and the apical area had a width of $2.48 \mu m \pm 0.45(n=15)$. The spigots presented smooth surfaces and were accompanying by very long stout setae with parallel ridges along the entire surface (Fig. 8B-C).

\subsubsection{Nemesiidae}

In all species, spigots were found close to the genital opening. Spigots are inserted in circular sockets in a number of more than 25 in most of species (Table 1). Results from the Kruskal-Wallis test found significant differences in the socket diameter $(H=21.84$, $p<0.001)$ and basal width $(H=17.02, p<0.001)$ among species. We found that $S$. platensis had the smallest sockets and basal width (Fig. 8D) in comparison with A. centralis (Fig. 8F) and D. ornata (Fig. 9A). As regards, the apical width, S. platensis and A. centralis had thinner apical portions than $D$. ornata $(H=15.41, p<0.001)$. Finally, regarding the length of the spigots $(H=15.48, p<0.001)$, A. centralis had the shorter spigots (Fig. 8F), while $D$. ornata had the longer ones (Fig. 9A) and S. platensis showed an intermediate length among the two mentioned species (Fig. 8D).

Epiandrous spigots were found to be curved at tip in $A$. centralis (Fig. 8F), and with a more erected shape in $D$. ornata and S. platensis (Figs. 8 D, 9 A). Spigots in the three species showed smooth surfaces. Regarding the intermixed setae with the epiandrous spigots, the three species had thin and short setae with small thorns along the entire surface (Fig. 8E). 


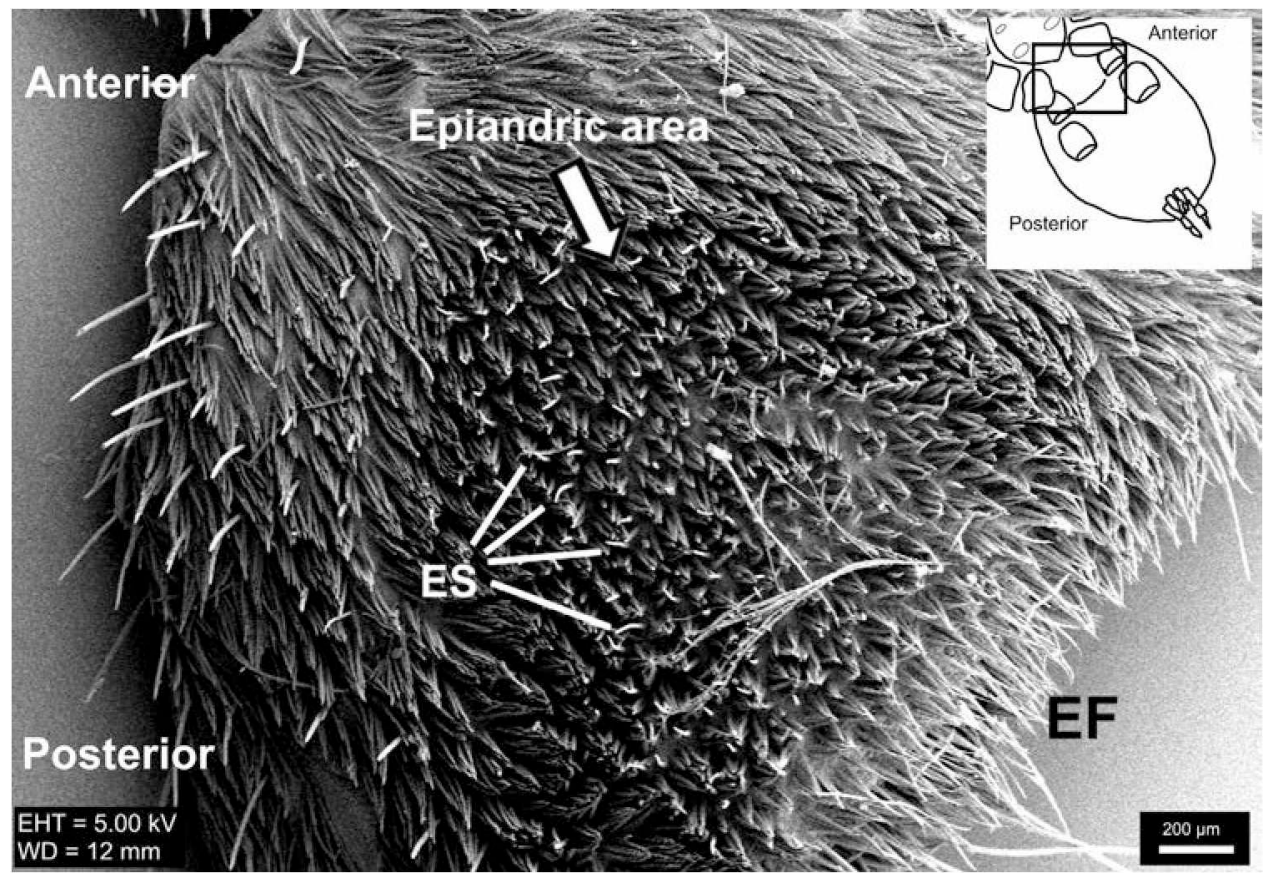

Fig. 4. Scanning electron micrograph showing epiandric area and spigots of Grammostola doeringi (Theraphosidae). ES=epiandrous spigot; EF=epigast ric fold.
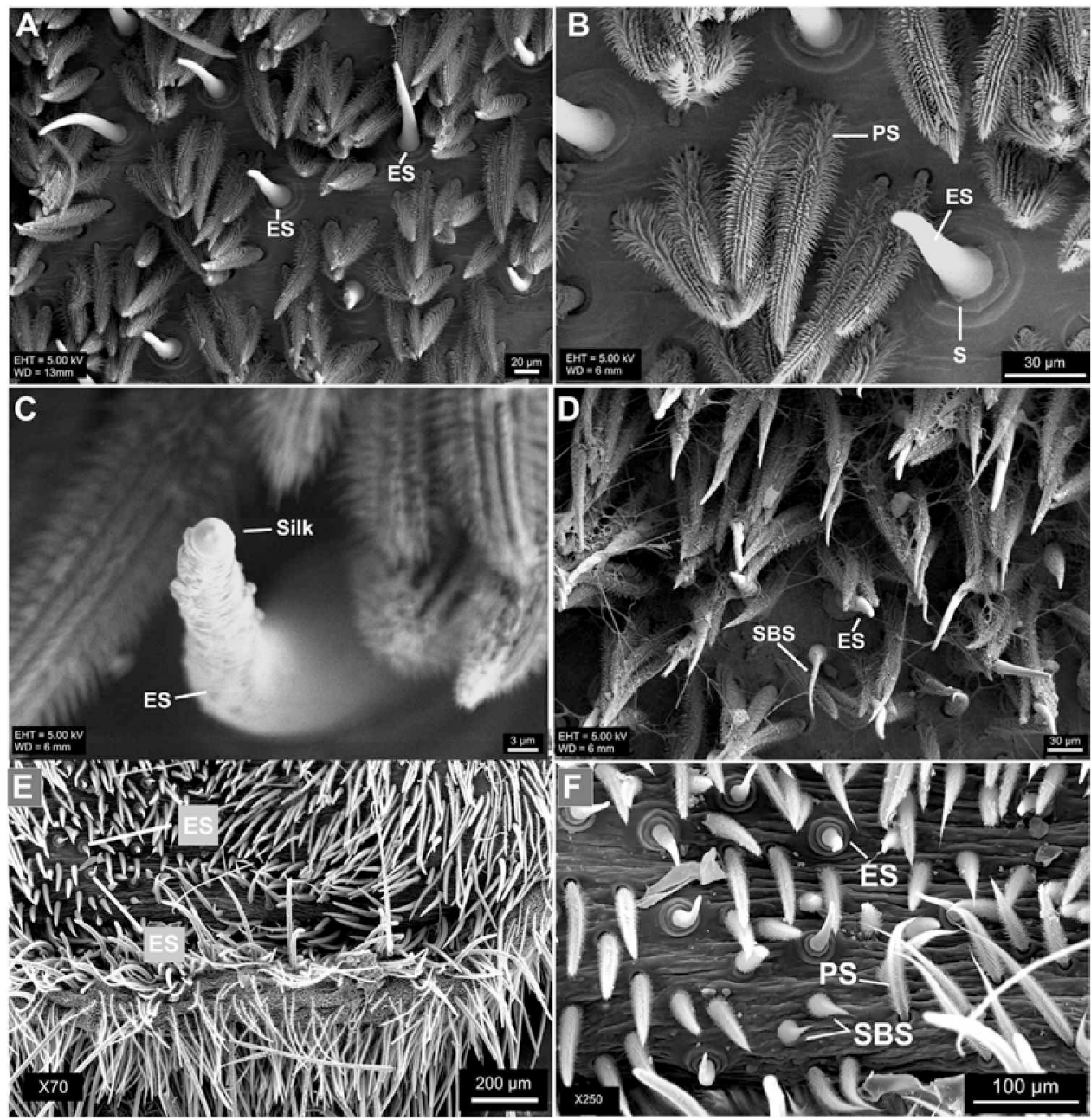

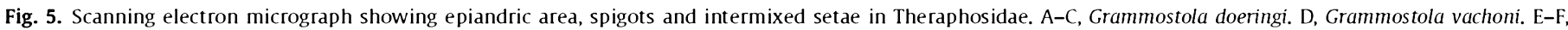
Homoeomma uruguayense. $\mathrm{ES}=$ epiand rous spigot; $\mathrm{PS}=$ plumose setae; $\mathrm{S}=$ socket; $\mathrm{SBS}=$ short blunt setae. 

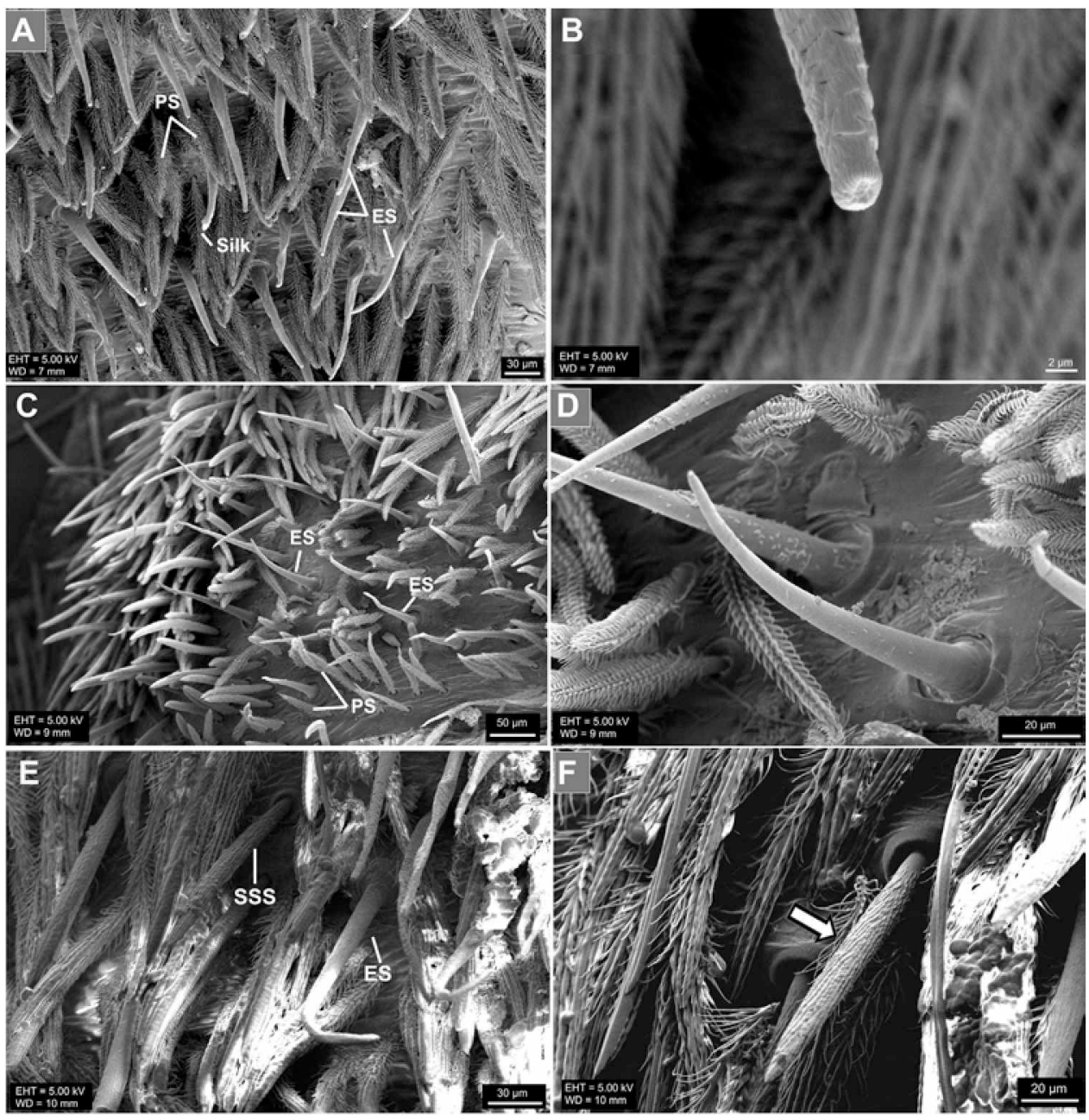

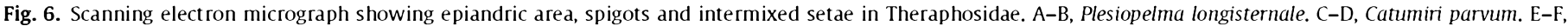
Melloleitaoina uru (white arrow indicates short stout setae). ES=epiandrous spigot; PS=plumose setae; SSS=short stout setae.

\subsubsection{Migidae (Calathotarsus simoni)}

We observed 27 epiandrous spigots (Table 1 ) above the genital opening (Fig. 9B). Spigots are inserted in circular rebordered sockets of $27.55 \mu \mathrm{m} \pm 3.79(\mathrm{n}=20)$ in diameter. The spigots are widened at base, curved at tip (mean length of $126.96 \mu \mathrm{m} \pm 23.01, \mathrm{n}=20$ ) and wider basally than apically (Fig. 9C-D). The basal portion showed a mean width of $19.33 \mu \mathrm{m} \pm 2.04(\mathrm{n}=20)$ and the apical area had a width of $4.79 \mu \mathrm{m} \pm 0.61 \quad(\mathrm{n}=20)$. The spigots presented smooth surfaces and were accompanying by short stout setae with small thorns along the entire surface (Fig. 9D).

\subsubsection{Idiopidae (Idiops $s p$.)}

Epiandrous spigots were found above the genital opening and in a number of 18 spigots (Table 1) (Fig. 9E). Spigots are inserted in circular bordered sockets of $23.32 \mu \mathrm{m} \pm 3.16(\mathrm{n}=13)$ in diameter. The spigots are straight and elongated or some curved at tip with a mean length of $86.81 \mu \mathrm{m} \pm 27.05(\mathrm{n}=13)$ and almost with the same width basally than apically (Fig. 9F). The basal portion showed a mean width of $10.96 \mu \mathrm{m} \pm 1.38(\mathrm{n}=13)$ and the apical area had a width of $5.39 \mu m \pm 0.83 \quad(n=13)$. The spigots showed smooth surfaces with very small thorns directed apically (Fig. 9F). Regarding the intermixed setae with the epiandrous spigots, Idiops sp. had long stout setae with small thorns on its surface (Fig. 9F).

Finally, we found significative differences from the ANOVA test of morphometrics parameters of epiandrous spigots between families of Mygalomorphae (Table 2). Regarding the socket diameter
Table 2

Results of one-way ANOVA test examining morphometric parameters of epiandrous spigots among families of Mygalomorphae, $p<0.05$. The same letters in a column do not significantly differ $(p>0.1)$.

\begin{tabular}{lllll}
\hline Family & Socket diameter & Basal width & Apical width & Length \\
\hline Actinopodidae & $\mathrm{BC}$ & $\mathrm{BC}$ & $\mathrm{CD}$ & $\mathrm{AB}$ \\
Dipluridae & $\mathrm{AB}$ & $\mathrm{BC}$ & $\mathrm{D}$ & $\mathrm{C}$ \\
Idiopidae & $\mathrm{BC}$ & $\mathrm{B}$ & $\mathrm{CD}$ & $\mathrm{AB}$ \\
Mecicobothriidae & $\mathrm{A}$ & $\mathrm{A}$ & $\mathrm{A}$ & $\mathrm{AB}$ \\
Microstigmatidae & $\mathrm{AB}$ & $\mathrm{B}$ & $\mathrm{AB}$ & $\mathrm{A}$ \\
Migidae & $\mathrm{C}$ & $\mathrm{D}$ & $\mathrm{D}$ & $\mathrm{C}$ \\
Nemesiidae & $\mathrm{B}$ & $\mathrm{BC}$ & $\mathrm{BC}$ & $\mathrm{C}$ \\
Theraphosidae & $\mathrm{C}$ & $\mathrm{C}$ & $\mathrm{D}$ & $\mathrm{B}$ \\
\hline
\end{tabular}

and basal width, Mecicobothriidae showed the lower values, while Migidae and Theraphosidae showed the higher mean values. We found a positive significant correlation between the basal width of the spigots and the size of the spider (Spearman correlation coefficient $\rho=0.643, p=0.004$ ). The apical width of epiandrous spigots was small on Mecicobothriidae, while the wider apical diameters were found in Dipluridae, Migidae and Theraphosidae. Concerning the length of epiandrous spigots, Microstigmatidae had the shorter ones, while Dipluridae, Migidae and Nemesiidae showed the longer spigots, but we found no significant correlation among the length of spigots and the size of the spider (Spearman correlation coefficient $\rho=0.367, p=0.133$ ). 

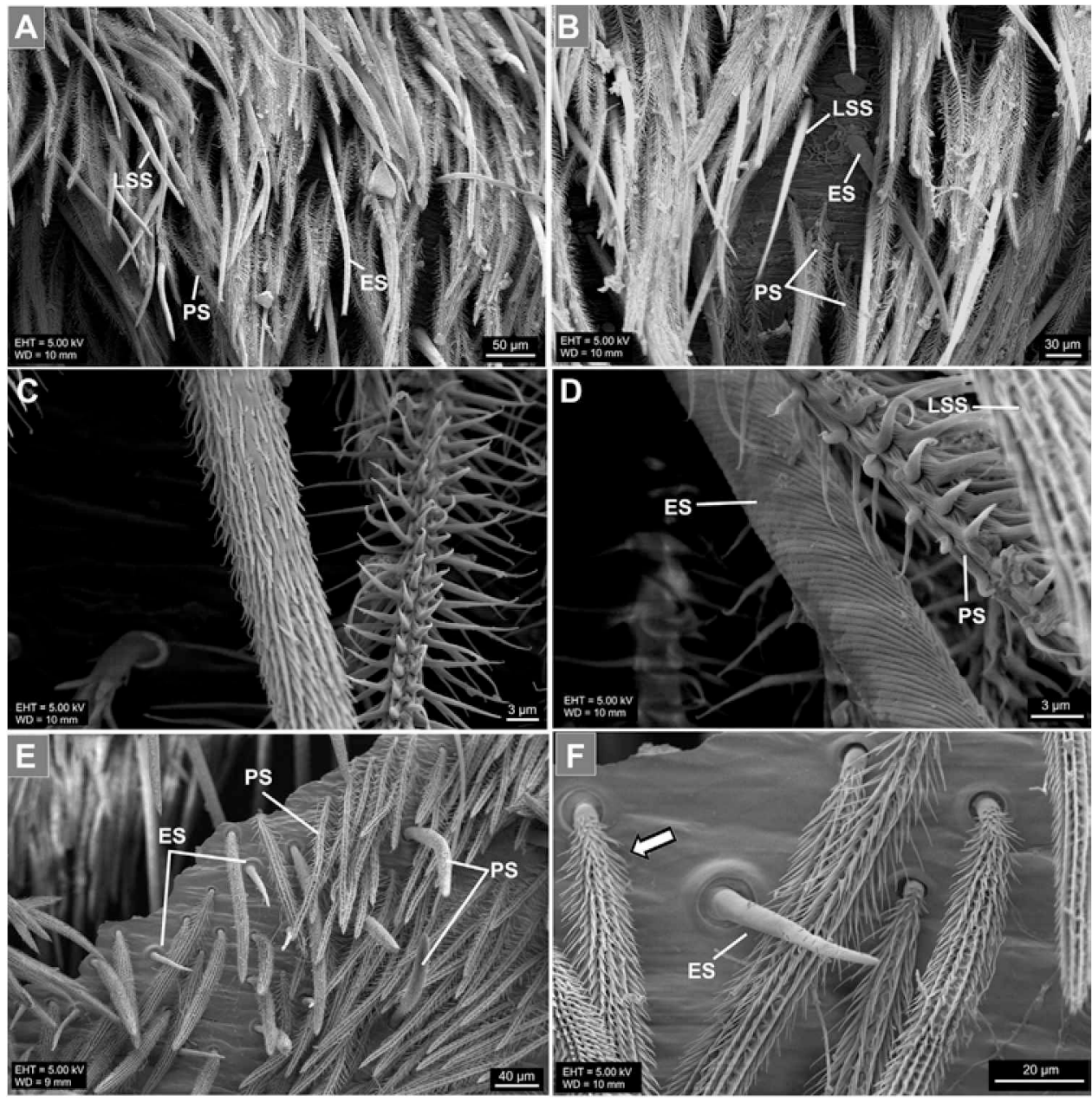

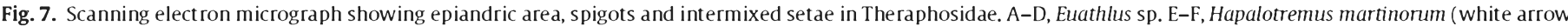
indicates plumose setae). $\mathrm{ES}=$ epiandrous spigot; LSS = long stout setae; $\mathrm{PS}$ = plumose setae.

\subsection{Morphology of epiandrous glands through histology}

In A. centralis (Nemesiidae) and G. vachoni (Theraphosidae), the epiandrous glands were observed as quadrangular or oval structures, with a large lumen lined by a tall columnar epithelium (Fig. 10A-C). Epithelial cells have a basal, spherical nucleus with thick patches of heterochromatin (Fig. 10B). Cytoplasm is full of acidophilous granules that react negatively to PAS and AB 2.5.

\section{Discussion}

Melchers (1964) and Marples (1967) found that epiandrous glands in mygalomorphs are cylindrical or pear-shaped and open to the exterior by means of stout hollow setae or fusule. Also, Marples (1967) said that the spigots arise on a transverse area on the anterior border of the genital furrow. In agreement, in all species studied, we found that epiandrous spigots are located immediately above the genital opening and two general spigot arrangements were identified: i) epiandrous spigots mixed among many plumose setae (found only in Theraphosidae), and ii) epiandrous spigots in a semicircular area above the genital opening mixed with scarce long setae (the rest of the studied families). The first pattern, characteristic of Theraphosidae, showed an evident half-moon shape above the genital opening formed by the plumose setae. It is wellknown among tarantula hobbyists that sub-adult males can be easily identified by observing this "half-moon" shape, thus, the area carrying the epiandrous spigots and plumose setae is prob- ably present before the male reaches adulthood. This comprises an important feature because it allows a quick and easy way to identify sub-adult males, an "impossible" task in mygalomorph spiders due to the absence of external indicative characters and this advantage could be useful in ecological or demographic studies. However, further developmental studies are needed to obtain information on how and when these epiandrous spigots appear.

According to Melchers (1964) and Marples (1967), the spigots arise in sockets in the cuticle and are tapering, but they do not have the cylindrical basal part and narrow distal part so often seen in the spigots of the spinnerets. In agreement, we found epiandrous spigots mostly arisen in circular sockets, but the hexagonal shape of the sockets found exclusively in Grammostola species is, herein, reported for the first time. Moreover, the ornamentation of epiandrous spigots (found in Dipluridae, Theraphosidae and Idiopidae) is also here reported for the first time. The different ornamentations observed in epiandrous spigots comprised: small or large ridges, transversal straight openings, small pores and squamate shapes along the entire surface. Some similar kinds of cuticule sculpturing, like lenticular, squamate, fluted or grooved have been reported for spinneret spigots (Coddington, 1989; Ramírez, 2014).

We found differences in the epiandrous spigot morphometrics, for example, Mecicobothriidae and Microstigmatidae were found to have the smaller spigots while Dipluridae, Migidae, Nemesiidae and Theraphosidae had the bigger and larger spigots. It could be expected that tarantulas (Theraphosidae) have the larger epiandrous spigots in all aspects since they comprised the biggest 

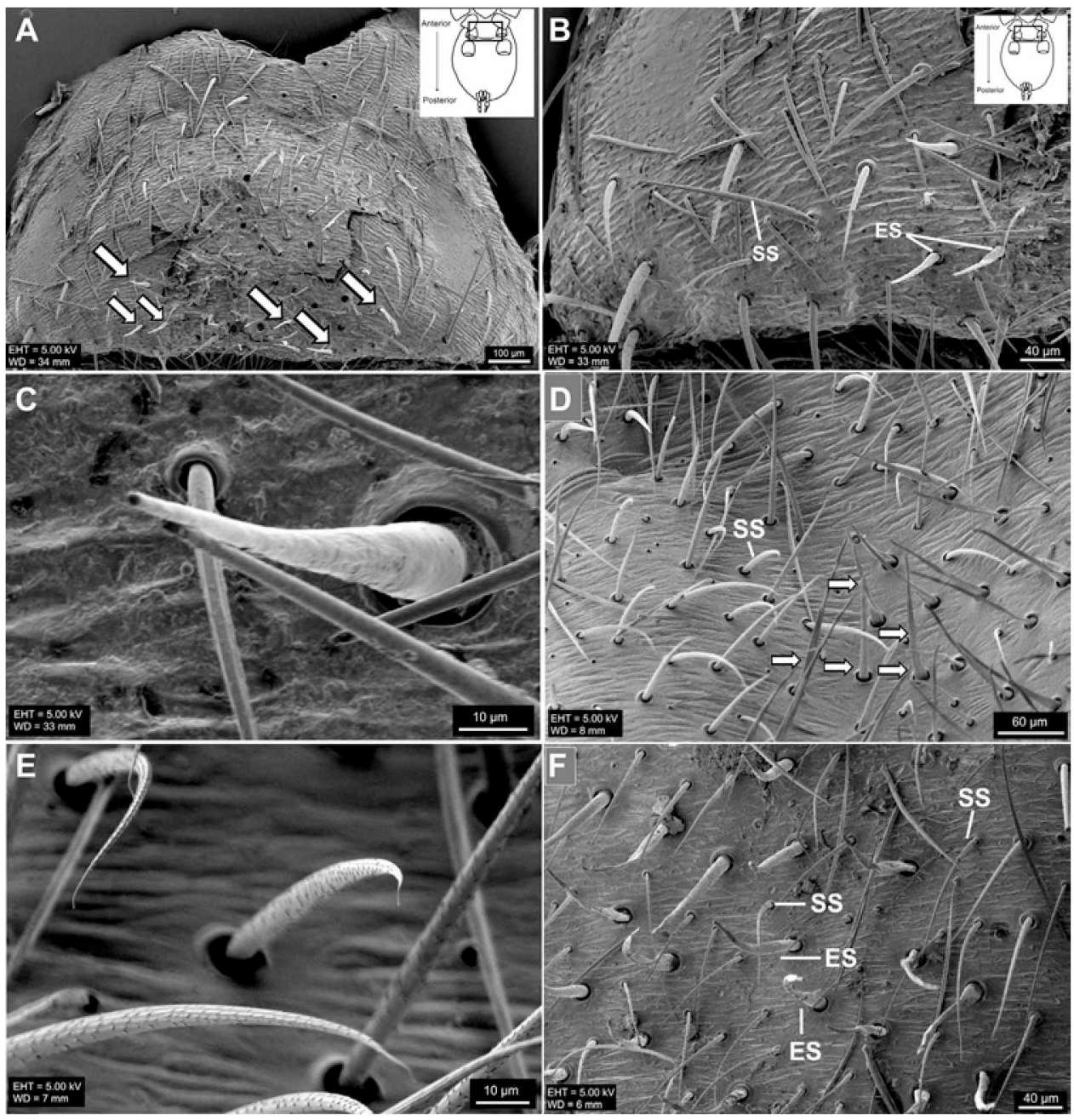

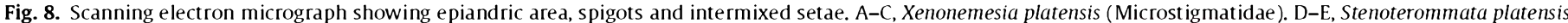
(Nemesiidae). F, Acanthogonatus centralis (Nemesiidae) (white arrows indicate epiandrous spigots). ES=epiandrous spigot: SS=stout setae.

mygalomorphs studied, but although they actually showed large spigots, no significant correlation was observed, thus representatives of Dipluridae, Migidae and Nemesiidae (medium and small sized mygalmorphs) had the longer spigots. Because differences in epiandrous spigot morphology among the families, genera and species studied were found, we suggest that this variation could not be easily associate with the taxonomic patterns. However, more studies are needed to elucidate this by incorporating a larger number of species and examining the morphology of epiandrous spigots in all known families. Also, a higher number of specimens could be examined in order to evaluate a possible correlation among the number of spigots and the size of the spider.

The function of epiandrous spigots comprises the release of silk just prior to ejaculation, when many male spiders display intense rubbing movements of the opisthosoma against the bridge of the sperm web and, at the end of the sperm induction, a silken line can be seen between the sperm droplet and the epiandrous spigot (Petrunkevitch, 1911, 1934; Baerg, 1928, 1958; Gerhardt, 1929, 1933; Knoflach, 1998; Costa and Pérez-Miles, 2002; Barrantes and Ramírez, 2013; Rojas-Buffet and Viera, 2016). In agreement, we observed apical openings of epiandrous spigots in all species studied and also, we were able to observe some silk lines emerging from the epiandrous spigots in some SEM pictures.

In araneomorph spiders, the epiandrous glands that are associated with the primary male reproductive system comprise multicellular glands located near the ductus ejaculatorius and open into epiandrous spigots (Michalik and Uhl, 2005). These epiandrous glands release their acinous substances near the genital opening through these special spigots or fusules (Lopez, 1974; Machado, 1951; Marples, 1967; López and Emerit, 1988). The fine structural analysis of Acanthogonatus centralis (Nemesiidae) glands agrees with those reported so far in Araneomorphae (Marples, 1967; Michalik and Uhl, 2005). The glandular epithelium of Grammostola vachoni (Theraphosidae) differs from the flat epithelium reported for some mygalomorphs (Melchers, 1964). This difference may be associated with the functional state of the gland, suggesting that epithelium height is directly proportional to the secretory activity of cells. The lack of reactivity to PAS and techniques such as AB, also suggest that glands secretion may be formed by protein molecules that occur for example in species of the genus Pucetia (Kovoor and Muñoz-Cueva, 1998).

\section{Acknowledgments}

Thanks to Natalia Difilippo for improving the English. Special thanks are addressed to Luis Pereira (MLP) and Matías Izquierdo, Monica Nime and Camilo Mattoni for loaning some specimens used in this study. SEM facilities were provided by the Centro Científico Tecnológico (CCT) (CONICET), Bahía Blanca. Thanks to Viviana Sorrivas for operating the SEM and her help on the photos. Nelson Ferretti and Alda González are researchers at CONICET. Sofía Cop- 


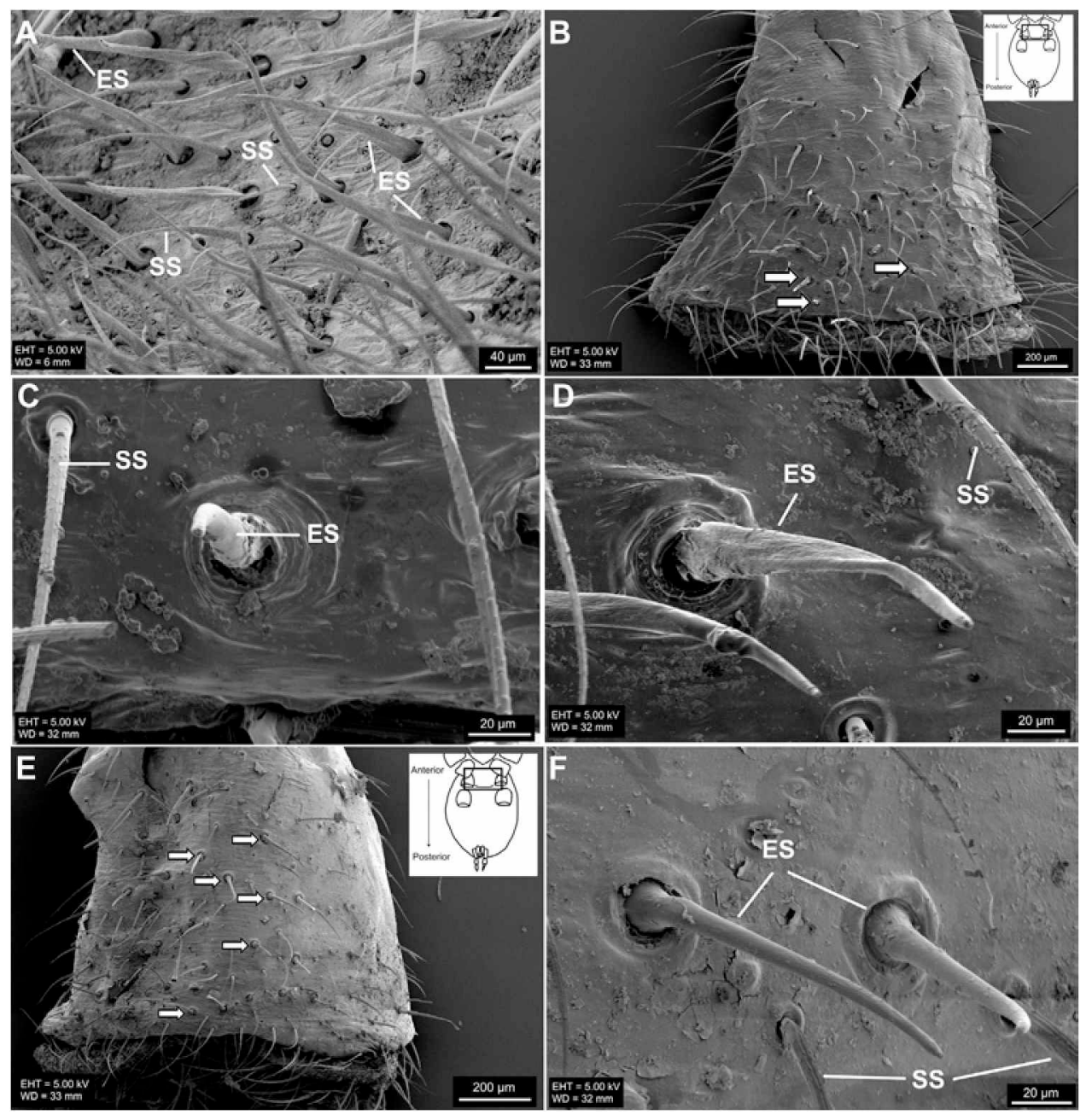

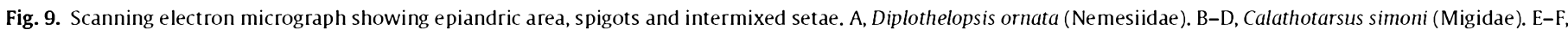
Idiops sp. (Idiopidae) (white arrows indicate epiandrous spigots). ES = epiandrous spigot; SS = stout setae.

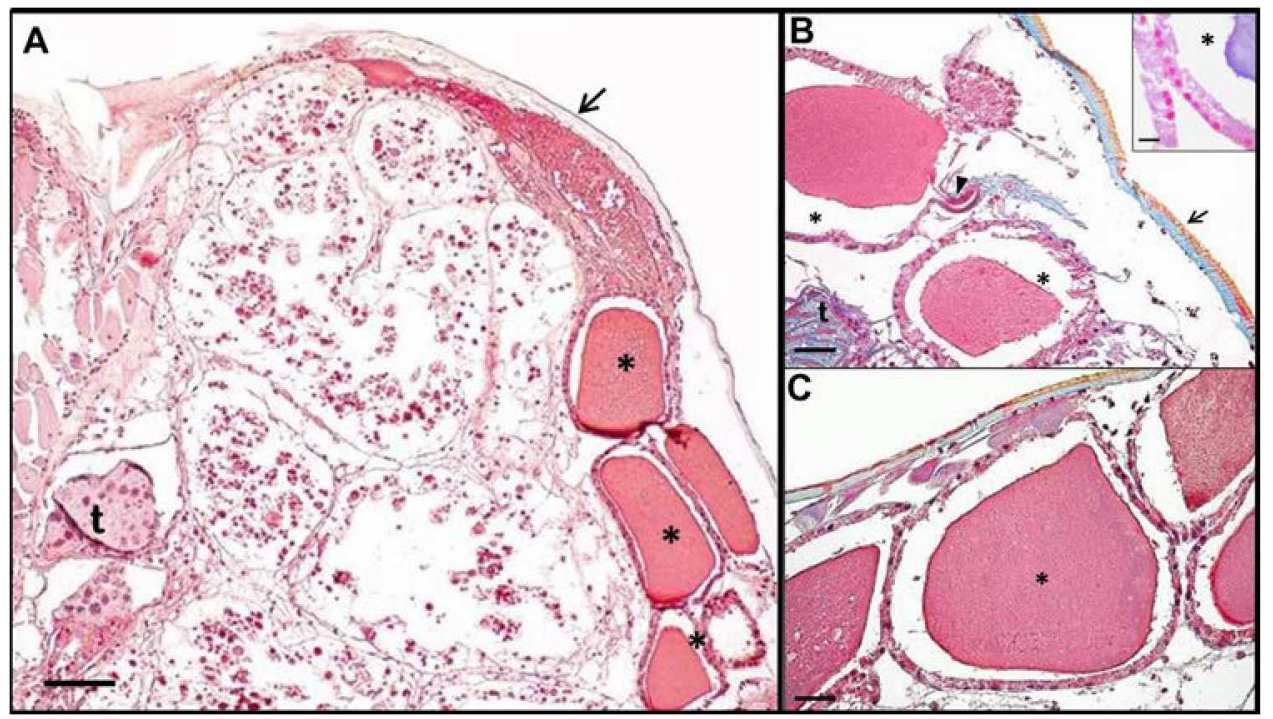

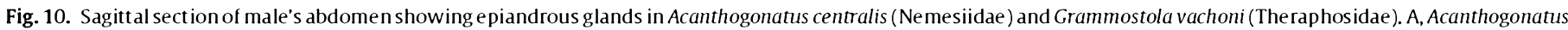

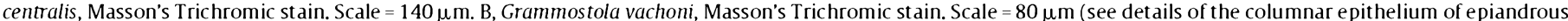

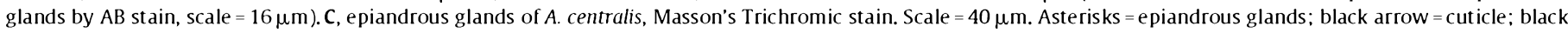
arrow head = glandular duct; $\mathrm{t}=$ test is. 
peri, Gabriel Pompozzi and Anahí Wehitt thank CONICET for their fellowships.

\section{References}

Agnarsson, I., 2004. Morphological phylogeny of cobweb spiders and their relatives (Araneae, Araneoidea, Theridiidae). Zool. J. Linn. Soc. 141 (4), 447-626.

Baerg, W.J., 1928. The life cycle and mating habits of the male tarantula. Quart. Rev. Biol. 3 (1), 109-116.

Baerg, W.J., 1958. The Tarantula. University of Kansas Press, Lawrence (88pp).

Barrantes, G., Ramírez, M.J., 2013. Courtship, egg sac construction, and maternal care in Kukulcania hibernalis, with information on the courtship of Misionellamendensis (Araneae, Filistatidae). Arachnology 16 (2), 72-80.

Bond, J., 2004. Systematics of the California neuctenizine spider genus Apomastus (Araneae: Mygalomorphae: Cyrtaucheniidae): the relationship between molecular and morphological taxonomy. Invertebr. Syst. 18, 361-376, htt p:// dx.doi.org/10.1071/IS04008.

Coddington, J.A., 1989. Spinneret silk spigot morphology: Evidence for the monophyly of orbweaving spiders, Cyrtophorinae (Araneidae), and the group of Theridiidae plus Nesticidae. J. Arachnol. 17, 71-95.

Costa, F., Pêrez-Miles, F., 2002. Reproductive biology of Uruguay antheraphosids (Araneae, Theraphosidae). J. Arachnol. 30 (3), 571-587.

Coyle, F.A., 1975. Systematics of the trapdoor spider genus Aliatypus (Araneae: Ant rodiaetidae). Psyche (Stuttg) 81 (3-4), 431-500, http://dx.doi.org/10.1155/ $1974 / 69634$.

Foelix, R.F., 2011. Biology of Spiders, 3rd ed. Oxford University Press, Oxford UK (419pp).

Gerhardt, U., 1929. Zur vergleichenden Sexualbiologie primitiver Spinnen, insbesondere der Tet rapneumonen. Zeits. Morph. Oekol. Tiere 14, 699-764.

Gerhardt, U., 1933. Neue Untersuchungen zur Sexualbiologie der Spinnen, insbesondere an Artender Mittelmeerländer und der Tropen. Zeits. Morph. Oekol. Tiere 27 (1), 1-75.

Hammer, Ø., Harper, D.A.T., Ryan, P.D., 2008. PAST_-Palaeontological Statistics, ver.1.81. Paleontological Museum, University of Oslo, Norway Onlineat:http://folk.uio.no/ohammer/past/index.html.

Knoflach, B., 1998. Mating in Theridion varians Hahnandrelatedspecies (Araneae: Theridiidae). J. Nat. Hist. 32 (4), 545-604, http://dx.doi.org/10.1080/ 00222939800770301.

Knoflach, B., 2004. Diversity in the copulatory behaviour of comb-footed spiders (Araneae, Theridiidae). Denisia 12, 161-256.

Kotzman, M., 1988. Sexual differentiation in juveniles of Selenocosmia stirlingi Hogg (Araneae: Theraphosidae) based on cuticular structures. Misc. Publ. Aust. Entomol. 5, 49-54.

Kovoor, J.J., Muñoz-Cueva, A., 1998. Structure and function of the silk-gland system in Oxyopidae (Araneae). In: Selden, P.A. (Ed.), Proceedings of the 17th European Colloquium of Arachnology, Edinburgh 1997. British Arachnological Society, Burnham Beeches, Bucks, pp. 133-141.
Kuntner, M., 2005. Arevision of Herennia (Araneae: Nephilidae: Nephilinae), the Australasian c̈oinspiders: Invertebr. Syst. 19 (5), 391-436, http://dx.doi.org/10. $1071 /$ ISO5024.

Labarque, F.M., Grismado, D.J., Ramírez, M., Yan, H., Griswold, C.E., 2009. The Southeast Asian genus Stedocys Ono, 1995 (Araneae: Scytodidae): first descriptions of female genitalia and a new species from China. Zootaxa 2297, $1-14$.

Legendre, R., Lopez, A., 1971. Les glandes épigastriques des Araignées males. C.R. Acad. Sci. 273, 1725-1728.

Legendre, R., Lopez, A., 1981. Observations histologiques complementaires chez l'araignee liphistiomorphe Heptathela kimurai Kishida, 1923 (Liphistiidae). Atti Soc. Tosc. Sci. Nat. Mem. Ser. B 88, 34-44.

Legendre, R., 1972. Les glandes épigastriques de la Mygale Scodra calceata Fabr. (Orthognatha, Theraphosidae). C.R. Acad. Sci. 274, 542-545.

Lopez, A., Emerit, M., 1988. New data on the epigastric apparatus of male spiders. Bull. Br. Arachnol. Soc. 7 (7), 220-224.

Lopez, A., 1974. Glandes épigastrique et classification des araneides. Bull. Ass. Anat. $58,899-904$

Machado, Machado, A. de B., 1951. Ochyroceratidae (Araneae) de l'Angola, 8. Publicações culturais da Companhia de Diamantes de Angola, pp. 9-87.

Marples, B.J., 1967. The spinnerets and epiandrous glands of spiders. Zool. J. Linn. Soc. 46 (310), 209-223.

Melchers, M., 1964. Zur Biologie der Vogelspinnen (Fam Aviculariidae). Zool. Morph. Oekol. Tiere 52 (5), 517-536.

Michalik, P., Uhl, G., 2005. The male genital system of the cellar spider Pholcus phalangioides (Fuesslin, 1775) (Pholcidae, Araneae): development of spermatozod and seminal secretion. Front. Zool. 2(1), 1-12, http://dx.doi.org/ 10.1186/1742-9994-2-12.

Miller, J.A., 2007. Review of Erigonine spider genera in the Neotropics (Araneae: Linyphiidae: Erigoninae). Zool. J. Linn. Soc. 149, 1-263, http://dx.doi.org/10. 1111/j.1096-3642.2007.00233.x.

Petrunkevitch, A, 1911. Sense of sight, courtship and mating in Dugesiella hentzi (Girard), a Theraphosid spider from Texas. Zool. Jahrb. Syst. 31, 355-376.

Petrunkevitch, A., 1934. New observations on molting and mating in tarantulae. J. N.Y. Ent. Soc. 42 (3), 289-296.

Ramírez, M., 2014. The morphology and phylogeny of Dionychan spiders (Araneae: Araneomorphae). Bull. Amer. Mus. Nat Hist. 390, 1-374, http://dx.doi.org/10. 5531/sd.sp.5.

Rohlf, F.J., 2006. tpsDig2 Digitize Landmarks and Outlines version 2.25. Dept. Ecol. \& Evol., St. Univ. NewYork, Stony Brook, NY.

Rojas-Buffet, C., Viera, C., 2016. Loading the male pedipalps: sperm induction in a subsocial spider. J. Arachnol. 44 (1), 96-98.

Shultz, J.W., 1987. The origin of the spinning apparatus in spiders. Biol. Rev. Camb. Philos. Soc. 62, 89-113, http://dx.doi.org/10.1111/j.1469-185X.1987.tb01263.x. 